\title{
Pengaruh Model Pembelajaran Problem Posing Terhadap Hasil Belajar Fisika
}

\author{
Mirnawati ${ }^{1}$, Bakhtiar ${ }^{2}$, Fatimah $^{3}$ \\ Program Studi Pendidikan Fisika STKIP Bima \\ Jl. Piere Tendean Kel. Mande Tel Fax (0374) 42801, Bima 84191, Indonesia \\ Email : fathmariama@gmail.com
}

\begin{abstract}
ABSTRAK : Penelitian ini adalah penelitian kuasi eksperimen dengan desain penelitian Non-Equivalent Control Group design yang bertujuan untuk mendapatkan ada tidaknya perbedaan terhadap hasil belajar fisika siswa antara yang diajar dengan model pembelajaran problem posing dan siswa yang diajar secara konvensional Kelas X SMA Negeri I Palibelo tahun pelajaran 2018/2019. Sampel dalam penelitian ini terdiri dari dua kelas yaitu siswa X IPAıdan kelas X IPA2 SMA Negeri IPalibelo dengan jumlah peserta didik sebanyak 54 orang. Pengolahan data hasil penelitian ini menggunakan analisis deskriptif dengan program SPSS untuk menggambarkan hasil belajar fisika siswa dan analisis inferensial untuk menguji hipotesis penelitian. Berdasarkan hasil analisis deskriptif menunjukkan bahwa setelah diterapkan model pembelajaran problem posing terhadap hasil belajar fisika siswa lebih tinggi dibandingkan dengan siswa yang menggunakan pembelajaran konvensional. Selanjutnya dianalisis juga menggunakan Normalitas, dimana hasil yang diperoleh untuk skor hasil belajar fisika pada kelas eksperimen lebih tinggi dibandingkan dengan kelas kontrol meskipun perbedaannya tidak berbeda jauh. Sedangkan untuk hasil uji hipotesis dua pihak menunjukkan bahwa Ho ditolak dan $\mathrm{H}_{a}$ diterima, jadi hasil yang diperoleh bahwa $\mathrm{H}_{a}$ diterima artinya terdapat perbedaan peningkatan antara kemampuan hasil belajar fisika yang diajar menggunakan model pembelajaran problem posing dengan siswa yang diajar secara konvensional siswa Kelas X SMA Negeri I Palibelo tahun pelajaran 2018/2019.
\end{abstract}

Kata kunci: Pembelajaran Problem Posing, Hasil Belajar

\section{PENDAHULUAN}

Mata pelajaran fisika adalah satu mata pelajaran dalam rumpun sains yang dapat mengembangkan kemampuan berfikir analitis induktif dan deduktif dalam menyelesaiakan masalah yang berkaitan dengan peristiwa alam sekitar, baik secara kualitatif maupun kuantitatif dengan menggunakan matematika, serta dapat mengembangkan pengetahuan, keterampilan, sikap percaya diri $[\mathrm{I}]$.

Pengajaran fisika selalu diikuti oleh pengerjaan soal-soal. Pengerjaan soal secara optimal dapat mengetahui hasil pembelajaran. Soal yang hanya memerlukan satu langkah berfikir, mengingat satu rumus dan hanya memasukan angkaangka ke dalam rumus, kurang berarti dalam membiasakan berfikir analisis. Untuk melatih kemampuan tersebut, diperlukan soal penyelesainya memerlukan langkah berfikir, yang memerlukan panduan dari beberapa konsep yang berkaitan $[2]$.

Saat peneliti melakukan observasi di beberapa sekolah, penyelesaian soal-soal fisika menggunakan format diketahui ,ditanya-kan dan jawab, bila diperhatikan secara cermat aspek analisis penyelesaian belum tampak, karena pada umumnya bagian penyelesaian langsung akhirnya. Penyelesaian soal-soal fisika yang terpenting adalah kerangka berfikir penyelesaiannya dan bukan perhitungan matematisnya. Hasil observasi juga diperoleh informasi bahwa kegiatan belajar mengajar berpusat pada siswa, kurangnya interaksi antara siswa dalam pembelajaran. Kurangnya kemampuan bekerja sama dalam belajar, kurang semangatnya siswa dalam mengerjakan tugas. Hal ini terlihat dari tugas-tugas latihan siswa. Siswa hanya menjawab dengan memasukan angka-angka ke dalam rumus yang telah ada. Ini disebabkan guru masih menggunakan metode yang lamah seperti: ceramah, tanya jawab, diskusi. Faktor penyebab yang lain belum bisa menyelesaikan suatu permasalahan yang didahului dengan kegiatan penyelidikan, faktor penggunaan model pembelajaran yang kurang tepat karena pembelajaran cenderung didominasi oleh pendidik yang pada tahap pelaksanaan pembelajaran dimulai dari menjelaskan materi, memberi contoh dan dilanjutkandengan latihan soal. Sehingga peserta didik kurang diberikan kesempatan untuk memikirkan dan menemukan konsep sendiri.

Dari permasalahan di atas salah satu upaya untuk mengatasi hal tersebut yaitu dibutuhkan suatu variasi model pembelajaran, strategi pembelajaran diantaranya model pembelajaran problem posing. Pada prinsipnya, model pembelajaran problem posing adalah suatu model pembelajaran yang mewajibkan para siswa untuk mengajukan soal sendiri melalui pelajaran soal (berlatih soal secara mandiri) Proses pelaksanaan model problen posing dicirikan dengan perumusan kembali soal yang telah diberikan pendidik. Oleh karena itu, penerapan problen posing dalam kegiatan pembelajaran dapat dilakukan secara individual maupun kelompok disekolah yaitu diawali dengan pendahuluan, pengembangan, penerapan dan penutup. Model pembelajaran problem posing menuntut siswa untuk terlibat secara aktif dalam proses kegiatan belajar mengajar [3]. Beberapa hasil penelitian telah menunjukan manfaat dari model pembelajaran problem posing. Yaitu merupakan salah satu bentuk kegiatan dalam pembelajaran fisika yang dapat mengaktifkan siswa, mengembangkan kemampuan berpikir siswa dalam menyelesaikan masalah serta menimbulkan sikap positif terhadap fisika [4].

\section{METODE PENELITIAN}

Penelitian ini menggunakan quasi eksperimen yaitu desain yang memiliki kelompok kontrol tetapi tidak berfungsi sepenuhnya untuk mengontrol variabel-variabel luar yang mempengaruhi pelaksanaan eksperimen [5]. Penelitian ini terdapat dua kelompok, pada kelompok eksperimen, yaitu peserta didik akan mendapatkan perlakuan dengan penggunaan 
model pembelajaran problem posing sedangkan kelompok kontrol mendapat perlakuan menggunakan model pembelajaran konvesional. Quasi-eksperimen design yang digunakan adalah post-test only control design dalam desain ini terdapat dua kelompok yang masing-masing dipilih secara random (R). Kelompok pertama diberikan perlakuan (X) dan kelompok yang lain tidak. Kelompok yang diberikan perlakuan disebut kelompok eksperimen dan kelompok yang tidak diberikan perlakuan disebut kelompok kontrol.

Tabel I. Desain penelitian

\begin{tabular}{ccc}
\hline Kelompok & Perlakuan & Posttest \\
\hline Eksperimen & $\mathrm{X}_{1}$ & $\mathrm{O}_{2}$ \\
\hline Kontrol & $\mathrm{X}_{2}$ & $\mathrm{O}_{4}$ \\
\hline
\end{tabular}

Adapun yang menjadi subyek populasi dalam penelitian ini adalah seluruh siswa kelas X SMA Negeri Palibelo. Pada penelitian ini dari populasi diambil dua kelas. Teknik sampel yang digunakan yaitu simmple random sampling yaitu pengambilan sampel secara acak tanpa memperhatikan strata yang ada dalam populasi itu. Semua anggota populasi diberi kesempatan yang sama untuk menjadi anggota sampel.

Pada penelitian ini untuk mengetahui hasil belajar fisika digunakan tes obyektif dalam bentuk pilihan ganda dengan jumlah 30 soal yang terdiri dari 5 alternatif pilihan. Siswa yang menjawab benar pada setiap butir soal diberi nilai I sedangkan siswa yang menjawab salah diberi nilai nol. Tes diberikan pada awal pembelajaran sebelum diberikan perlakuan (pretest) untuk melihat kemampuan awal siswa kelas eksperimen maupun kelas kontrol dan setelah diberikan perlakuan (posttest) untuk melihat pengaruh hasil belajar peserta didik dengan menerapkan model Problem Posing.

Data penelitian yang diperoleh kemudian diolah dan dianalisis agar dapat dipahami bukan hanya peneliti, maka data yang diperoleh harus diuraikan melalui analisis data.

I. Uji Prasyarat Analisis

a. Uji Normalitas

Uji normalitas digunakan untuk mengetahui data yang dianalisis berdistribusi normal atau tidak. Uji statistika yang digunakan adalah uji chi-kuadrat dengan rumus :

$$
X^{2}=\sum_{i=1}^{k} \frac{\left(O_{i}-E_{i}\right)^{2}}{E_{i}}
$$

Hasil uji normalitas diterima jika $X^{2}{ }_{\text {hitung }}<X^{2}{ }_{\text {tabel }}$ tabel pada taraf signifikansi 5\% [6].

b. Uji Homogenitas

Untuk mengetahui bahwa kedua sampel memiliki varians yang homogen dilakukan pengujian kesamaan dua varians dengan menggunakan uji $F$ yaitu sebagai berikut:

$$
F_{\text {hitung }}=\frac{\text { Varians terbesar }}{\text { Varians terkecil }}
$$

Setelah diketahui kedua sampel homogen atau tidak kemudian analisisi data dengan menggunakan rumus t-tes. Apabila varians homogen rumus yang digunakan untuk menguji hipotesis adalah menggunakan rumus $t$-tes polled varians yaitu [5]:

$$
\mathrm{t}=\frac{\bar{x} 1-\bar{x} 2}{\sqrt{\frac{\left(n_{1}-1\right) S_{1}^{2}+\left(n_{2}-1\right) S_{2}^{2}}{n_{1}+n_{2}-2}\left[\frac{1}{n_{1}}+\frac{1}{n_{2}}\right]}}
$$

\section{HASIL DAN PEMBAHASAN}

Dari hasil analisis maka dapat dilihat pada tabel dibawah ini. Hasil Pre-test yang diperoleh untuk kelas eksperimen dan kontrol adalah sebagai berikut:

Tabel 2. Data Pre-test Siswa

\begin{tabular}{lllll}
\hline Kelas & $\begin{array}{l}\text { Nilai } \\
\text { tertinggi }\end{array}$ & $\begin{array}{l}\text { Nilai } \\
\text { terendah }\end{array}$ & $\begin{array}{l}\text { Jumlah } \\
\text { nilai }\end{array}$ & $\begin{array}{l}\text { Rata- } \\
\text { rata }\end{array}$ \\
\hline Eksperimen & 85 & 35 & I6I5 & $59,8 \mathrm{I}$ \\
\hline Kontrol & 70 & 30 & I455 & 53,89 \\
\hline
\end{tabular}

Selanjutnya setelah diberikan tes awal (pre-test) siswa diajarkan dengan menggunakan model pembelajaran problem posing pada kela eksperimen dan kelas kontrol diajarkan metode konvensional. Setelah proses pembelajaran selesai, siswa diberikan tes akhir (post-test) dengan soal yang sama dan jumlah soalnya sebanyak 19 nomor. Jadi, hasil yang diperoleh dapat dilihat pada tabel di bawah ini.

Hasil Pos-test yang diperoleh untuk kelas eksperimen dan kelas kontrol adalah sebagai berikut:

Tabel 3. Data Pos-test Siswa

\begin{tabular}{lllll}
\hline Kelas & $\begin{array}{l}\text { Nilai } \\
\text { tertinggi }\end{array}$ & $\begin{array}{l}\text { Nilai } \\
\text { terendah }\end{array}$ & $\begin{array}{l}\text { Jumlah } \\
\text { nilai }\end{array}$ & $\begin{array}{l}\text { Rata- } \\
\text { rata }\end{array}$ \\
\hline Eksperimen & 95 & 70 & 424 & 81,54 \\
\hline Kontrol & 75 & 45 & 327 & 60,56 \\
\hline
\end{tabular}

I. Uji Prasarat Analisis

a. Uji Normalitas

Uji normalitas adalah uji statistik yang digunakan untuk mengetahui apakah data tersebut berdistribusi normal atau tidak. Berdasarkan hasil pos-test dilakukan uji normalitas untuk mengetahui distribusi hasil yang diperoleh dan untuk uji normalitas data, telah ditetapkan kriteria pengujian bahwa data dikatakan berdistribusi normal jika $X^{2}$ hitung $<X^{2}$ tabel pada taraf signifikan $5 \%$ dengan $(\mathrm{dk})=\mathrm{k}-\mathrm{I}$.

I) Kelompok yang diajarkan dengan menggunakan model pembelajaran problem posing (kelompok eksperimen).

Berdasarkan perhitungan dapat diketahui bahwa dengan membandingkan $x^{2}$ hitung dengan nilai $x^{2}$ tabel untuk $\alpha=0,05$ dan derajat kebebasan (dk) $=$ k$\mathrm{I}=4-\mathrm{I}=3$, maka dicari pada tabel chi kuadrat 
didapat $x_{\text {tabel }}^{2}=7,815$, oleh karena $x^{2}$ hitung nilainya $=4,99 \leq x_{\text {tabel }}^{2}=7,815$ maka data terdistribusi normal.

2) Kelompok yang diajarkan tanpa menggunakan model pembelajaran problem posing (kelas kontrol).

Perhitungan di atas dapat di ketahui bahwa denga membandingkan $x^{2}$ hitung dengan nilai $x^{2}$ tabel untuk $\alpha=0,05$ dan derajat kebebasan $(\mathrm{dk})=\mathrm{k}-\mathrm{I}=$ 5-I $=4$, maka dicari pada tabel chi kuadrat didapat $x_{\text {tabel }}^{2}=9,488$, oleh karena $x_{\text {hitung }}^{2}=65,99 \leq$ $x_{\text {tabel }}^{2}=9,455$, maka data terdistribusi normal.

b. Uji Homogenitas

Uji homogenitas digunakan untuk membuktikan apakah kedua sampel yang menjadi obyek penelitian homogen atau tidak. Berdasarkan tabel disampin, bahwa $F_{\text {hitung }}=$ I,87, maka perlu dibandingkan dengan $F_{\text {tabel }}$ dengan $\mathrm{dk}$ pembilang $27-\mathrm{I}=26 \mathrm{dan} \mathrm{dk}$ penyebut $27-\mathrm{I}=$ 26. Berdasarkan $\mathrm{dk}$ pembilang $26 \mathrm{dan} \mathrm{dk}$ penyebut 26 , dengan taraf kesalahan ditetapkan 5\%, maka harga $F_{\text {tabel }}$ $=2,4 \mathrm{I}$ karna harga $F_{\text {hitung }}(\mathrm{I}, 87)$ lebih kecil dari harga $F_{\text {tabel }}(2,4 \mathrm{I})$. Maka berdasarkan kritaria pengujian jika harga $F_{\text {hitung }}$ lebih kecil atau sama dengan $F_{\text {tabel }}(\mathrm{Fh}<$ Ft) maka varians homogen.

Tabel 4. Uji Homogenitas Varians Populasi

\begin{tabular}{|c|c|c|c|c|c|c|}
\hline Kelas & $\begin{array}{l}\text { Rerat } \\
\text { a }\end{array}$ & $\begin{array}{l}\text { Varia } \\
\text { ns }\end{array}$ & $F_{\text {hitung }}$ & $\begin{array}{c}F_{\text {tabel }} \text { Tar } \\
\text { af }\end{array}$ & $\mathrm{dk}$ & Ket \\
\hline $\begin{array}{l}\text { Eksper } \\
\text { imen }\end{array}$ & 81,48 & $\begin{array}{l}\text { I72,6 } \\
\text { I }\end{array}$ & $\mathrm{I}, 87$ & $5 \%$ & 27 & $\begin{array}{l}\text { Hom } \\
\text { ogen }\end{array}$ \\
\hline $\begin{array}{l}\text { Kontro } \\
1\end{array}$ & 60,56 & 92,35 & & I & 27 & \\
\hline
\end{tabular}

c. Uji hipotesis

Dari hasil perhitungan uji-t polled varians diperoleh $t_{\text {hitung }}$ sebesar 6,68 dan harga $t_{\text {tabel }}=1,67$ untuk taraf signifikasi 5\% dengan derajat kebebasan $\mathrm{dk} n \mathrm{n}$ $+\mathrm{n} 2-2=27+27-2=52$, (harga antara dk 40 dan 60). Oleh karena $t_{\text {hitung }}$ lebih besar dari $t_{\text {tabel }}(6,68>1,67)$, maka dapat disimpulkan bahwa Ho ditolak dan $\mathrm{Ha}$ diterima pada hasil belajar fisika pada pokok bahasan besaran fisika dan pengukurannya yang diajarkan dengan menggunakan model pembelajaran problem posing lebih baik dari pada siswa yang diajarkan tanpa menggunakan model pembelajaran problem posing pada siswa kelas $\mathrm{X}$ IPA I semester ganjil SMA Negeri I Palibelo tahun pelajaran 2018/2019. Berdasarkan hasil analisis hipotesis yang dilakukan, diperoleh $\mathrm{t}_{\text {hitung }}=6,68$ dan harga $\mathrm{t}_{\text {tabel }}$
$=1,67$ untuk taraf signifikan $5 \%$ dengan derajat kebebasan (harga antara $\mathrm{dk} 40$ dan 60). Oleh karena $\mathrm{t}_{\text {hitung }}$ lebih besar dari $\mathrm{t}_{\text {tabel }}(6,68>\mathrm{I}, 67)$.

Jadi dapat disimpulkan bahwa untuk pengujian hipotesis (Uji-t) jika $t_{\text {hitung }}$ lebih kecil dari $t_{\text {tabel }}$ maka Ho diterima dan Ha ditolak dan jika $t_{\text {hitung lebih besar dari }}$ $t_{\text {tabel }}$ maka Ho ditolak dan Ha diterima. Maka hasil penelitian di atas dapat disimpulkan bahwa Ha diterima dan Ho ditolak. Artinya terdapat pengaruh penggunaan model pembelajaran problem posing terhadap hasil belajar fisika siswa kelas X SMA Negeri I Palibelo tahun pelajaran 2018/2019.

\section{KESIMPULAN}

Berdasarkan hasil penenlitian dapat disimpulkan bahwa ada pengaruh yang signifikan pengajaran menggunakan model pembelajaran problem posing dan untuk mengetahui hasil belajar Fisika siswa pada materi pokok besaran Fisika dan pengukurannya, dari pada siswa yang diajarkan tanpa menggunakan model pembelajaran problem posing pada siswa kela X IPA I semester ganjil SMA Negeri I Palibelo tahun pelajaran 2018/2019, dimana rata-rata untuk kelas eksperimen 8I,48 dan untuk kelas kontrol 60,56.

\section{DAFTAR PUSTAKA}

[I] Fahturrohman \& Sulistyorini. 20II. Belajar dan Pembelajaran. Giancoli. FISIKA Edisi Kelima. Jakarta: Erlangga

[2] Astra. 2012. Pengaruh Model Pembelajaran Problem Posing Terhadap Hasil Belajar Fisika. Jurnal Pendidikan Fisika Indonesia.

3] Wulandari, Laksmi. 200I. Penerapn Model Pembelajaran Problem Posing dengan Metode Tugas Terstruktur dalam Pembelajaran Fisika SMA. Jurnal Pembelajar Fisika

[4] Muhibin Syam. 2008 Psikolog Pendidik dengan Pendidikan Baru. Bandung: PT Rem Rosida Karya.

[5] Sugiono. (2011). Metode Penelitian Kuantitatif Kualitatif dan R\&D. Bandung : Alfabeta

[6] Sudjana, N. (2002). Metode Statistik Edisi ke-6. Bandung : Tarsito 